\title{
A oralidade no novo código de processo penal da nação Argentina ${ }^{1}$
}

\author{
The orality in the new criminal procedure \\ code of the argentine nation
}

\section{Leonel González Postigo}

Centro de Estudios de Justicia de las Américas (CEJA) - Santiago/Chile leonel.gonzalez@cejamericas.org

orcid.org/0000-0001-7924-7791

\section{Tobías José Podestá}

Centro de Estudios de Justicia de las Américas (CEJA) - Santiago/Chile podestatobias@gmail.com orcid.org/0000-0002-9792-4255

Resumo: O novo Código de Processo Penal da Nação Argentina estabeleceu um sistema de audiências orais. Neste artigo se descrevem as principais mudanças de cada etapa processual, em conjunto com a identificação dos desafios colocados para a dinâmica das audiências.

Palavras-chave: Processo Penal; oralidade; Argentina.

AbstRact: The new Criminal Procedure Code of the Nation of Argentina established a system of oral hearings. This article describes the main changes of each stage of the process together with the identification of the challenges involved in the dynamics of the audiences.

KEYwORDs: Criminal procedure; oral ity; Argentina.

1 Este artigo é uma versão resumida e traduzida para português do trabalho Oralidad en el nuevo Código Procesal Penal de la Nación Argentina, publicado na Revista de Derecho Procesal Penal, Santa Fe, Argentina, 2015. Tradução de Caíque Ribeiro Galícia e Vinícius Diniz Monteiro de Barros. 


\section{INTRODUÇÃO}

O presente trabalho se ocupará de analisar a oralidade no novo Código Processual Penal da Nação (doravante, CPPN) como metodologia de trabalho para que as partes formulem suas pretensões e os juízes decidam, ao longo de todo o processo.

A promulgação da Lei $27.063^{2}$ (2014) provou-se um grande feito, ao aprovar um novo Código de Processo Penal da Nação Argentina, de matriz acusatória que incorpora vários institutos processuais com a finalidade de permitir os exercícios de direitos em diversos corpos normativos supralegais. ${ }^{3}$ Sem embargo, pelo decreto presidencial $257 / 2015^{4}$ se postergaram aqueles aspectos vinculados à sua implantação, com base nos conteúdos dos informes elaborados pela Comissão Bicameral de Monitoramento e Implantação do Novo Código de Processo Penal da Nação e pela União de Pessoal da Justiça da Nação. O diferimento, por ora indefinido (ou ao menos até maio de 2017), ficará sujeito ao cronograma de implantação progressiva que a aludida Comissão Bicameral estabeleça, à prévia consulta com o Ministério da Justiça e Direitos Humanos e com o Conselho da Magistratura, ambos da Nação. Chama a atenção que não se integre a todos os organismos do

2 Disponívelem:<http://www.saij.gob.ar/se-promulgo-ley-27063-aprobacion-nuevo-codigo-procesal-penal-nacion-se-promulgo-ley-27063-aprobacion-nuevo-codigo-procesal-penal-nacion-nv9812-2014-12-04/123456789-0abc-d21-89ti-lpssedadevon>. Acesso em: 25 jul. 2017.

3 De modo não taxativo se pode mencionar: traz clareza e precisão aos papéis das partes; fortalece o poder dos juízes, reservando sua intervenção apenas ao âmbito jurisdicional; valoriza o julgamento como instância institucional para a resolução de conflitos; procura eficiência global do sistema, ao diminuir e controlar os prazos de investigação (113 CPPN); prevê investigações de casos complexos (293 e seguintes CPPN); favorece uma maior participação da vítima (78 CPPN); estabelece novas formas de composição de conflitos (34 CPPN); estende a oralidade a todas as fases do processo e evita a delegação das funções (2 CPPN); estipula medidas do coerção pessoal regradas; estipula como fundamento para a revisão judicial a nova jurisprudência dos organismos internacionais (318 CPP); altera o regime da nulidades; incorpora a suspensão do juízo (250 CPPN); garante a publicidade e o acesso dos meios de comunicação (253 e 254) etc.

4 B.O. $29 / 12 / 2016$. 
sistema de justiça penal, como a Defensoria Pública (Ministério Público da Defesa) e o Ministério Público (Fiscal) ${ }^{5}$.

Essa situação conjuntural incerta não deve ser um impedimento para que se difundam diversas opiniões técnicas sobre os institutos processuais emergentes do novo ordenamento processual penal da nação Argentina. Embora não sejam novidades no plano do direito comparado, podem ter um impacto nos operadores judiciais da justiça nacional da Cidade Autônoma de Buenos Aires e da Justiça Federal de todo o país.

Já ingressando no tema concreto do trabalho, o novo CPPN categoriza a oralidade como um princípio (art. 2. ${ }^{\circ} \mathrm{CPPN}$ ), mesmo que seja um instrumento ou mecanismo de comunicação ${ }^{6}$. Isso não modifica sua relevância pois "é o único modo eficaz que nossa cultura encontrou até o momento para dar a ele verdadeira positividade ou vigência aos princípios políticos (...) Por ser condição necessária de eficácia desses princípios, a oralidade se converte em um instrumento de primeira ordem (...)."7

Essa nova forma de trabalho permitirá humanizar o processo e substituir o trabalho escrito e delegável aos empregados e funcionários que dependem do juiz. Permite um contato imediato e concentrado das partes com o juiz, facilitando a entrega direta de informação de qualidade sobre o caso (com a possibilidade de a outra parte a contradizer); e só a partir desse conjunto de informações poderá decidir. Em outros termos, opera sobre a base de reunir os atores interessados e que se gere entre eles um intercâmbio verbal sobre as posições e argumentos que cada um sustenta, para que mais tarde e no mesmo ato, salvo exceções, se defina motivadamente a controvérsia. Dessa forma, decide-se no mesmo momento, com pleno exercício de seus direitos e dotando as decisões jurisdicionais de adequada publicidade.

5 A seu tempo apresentaram-se projetos para modificar o atual Código de Processo Penal (Lei 23.984), assim como o processo de flagrância (Leu 27.272), que culminaram por dilatar a vigência do novo sistema de justiça.

6 CANO JARAMILLO Carlos Arturo; Oralidad, Debate y Argumentación. 2da reimpresión; Bogota; Editorial Ibañez, 2007.

7 BINDER Alberto; Introducción al derecho procesal penal; Ad Hoc, Buenos Aires, 2005, p. 101. 
Como se pode notar, a oralidade constitui na realidade um modelo de trabalho que coloca a sala de audiência como o espaço natural para o trabalho dos juízes e das partes.

Essa mudança de modelo, que significa a substituição do expediente pela audiência como fonte de produção e depuração da informação, envolve uma completa transformação na forma de conceber o processo.

As experiências latino-americanas têm demonstrado as enormes dificuldades e retrocessos na implantação da oralidade ao longo dos últimos anos ${ }^{8}$. Com base nesses antecedentes é que pretendemos adiantar as possíveis interpretações ou desvios do novo sistema de audiências adotado para a justiça federal argentina.

\section{Oralidade na etapa preparatória}

A "etapa preparatória" possui dois objetivos: 1.- estabelecer se existe ou não mérito suficiente para inaugurar um juízo a respeito de uma ou mais condutas com relevância jurídica penal (art. 195 CPPN) e 2.- propiciar a utilização de meios alternativos de resolução de conflitos (art. 34 e 35 CPPN).

De acordo com a regra que o código estabelece para esta etapa, o juiz deverá proferir todas as decisões jurisdicionais em audiência (art. 199 CPPN), conforme os princípios gerais que assinalamos no tópico anterior (art. 2 CPPN) e o disposto no art. 105 do CPPN.

Nesta etapa, podem-se fazer diferentes classificações sobre as hipóteses em que é necessária uma decisão jurisdicional; uma dela pode ser se os casos possuem caráter unilateral, bilateral ou multilateral; no nosso caso, faremos uma divisão temática, em três áreas: tramitação, meios de coleta e/ou produção de prova e medidas de coerção e cautelares. Para além desta classificação, deve-se notar que as audiências não

8 Entre as manifestações contrárias à oralidade, tem-se evidenciado que nos processos de reforma persistiu um papel muito ativo de juízes na produção de informações durante o processo; a suspensão de audiências sem causa justificada; a escassa preparação das partes; ou a incorporação de prova por leitura etc. Cfr. Projeto de acompanhamento dos processos de reforma judicial na América Latina, disponível no site virtual do CEJA. 
têm apenas o propósito para o qual foram solicitadas ou convocadas, mas reúnem a qualidade de haver "multipropósitos"; não deveria haver obstáculos e/ou impedimentos para que nelas se tratem outras questões que excedam os objetivos iniciais para os quais foi convocada.

\subsection{DA TRAMITAÇÃO}

Durante a investigação preparatória ou etapa preliminar, os juízes deverão decidir, ante o pedido de intervenção de alguma das partes do processo, nas seguintes hipóteses: homologação do acordo de conciliação entre o imputado e a vítima (art. 34 \$1. $\left.{ }^{\circ} \mathrm{CPPN}\right)$; reabertura da investigação ante o descumprimento do acordo de conciliação (art. 34 $\S 2 .{ }^{\circ} \mathrm{CPPN}$ ); audiência de suspensão do juízo de prova [suspensão condicional do processo] (art. $35 \mathrm{CPPN}$ ); por descumprimento das condições estabelecidas na suspensão do juízo de prova [suspensão condicional do processo] (art. 35 CPPN); para levantar as exceções arroladas no art. 37 (art. $38 \mathrm{CPPN}$ ); recusa [impedimento ou suspeição] do juiz (art. $61 \mathrm{CPPN}$ ); inimputabilidade no momento do fato (art. $66 \mathrm{CPPN}$ ); doença mental superveniente (art. $67 \mathrm{CPPN}$ ); declaração de revelia (art. $68 \mathrm{CPPN}$ ); quando o imputado estiver foragido ou, se presente, tiver sido colocado à disposição da autoridade requerente (art. $68 \S 4 .^{\circ}$ CPPN); constituição de querelante (e parte civil [assistente]) ante a negativa por falta de legitimidade do membro do Ministério Público Fiscal (art. 83, 94, 42 e 209 CPPN); desistência do querelante (art. 84 CPPN); desistência da parte civil [assistente] (art. $96 \mathrm{CPPN}$ ); reserva [pedido] total ou parcial de arquivamento da investigação (art. $201 \mathrm{CPPN}$ ); prorrogação da investigação prévia à formalização da investigação (art. 220 CPPN); formalização da investigação (art. 221 CPPN); ampliação do objeto de investigação (art. $226 \mathrm{CPPN}$ ); para modificação do prazo da investigação, seja sua redução (art. 232 CPPN), seja sua prorrogação (art. 233 CPPN); entre outros.

\subsection{MEIOS DE PROVA}

Os meios de coleta e/ou produção de prova que exigem autorização judicial são os seguintes: negativa do Ministério Público para a 
coleta de prova em que seja necessário o uso do poder de polícia (art. 128 b e 227 CPPN); requisição (art. 130 CPPN), pedido de busca e apreensão domiciliar ou pessoal (art. $136 \mathrm{CPPN}$ ); manutenção do sequestro [apreensão] dos objetos que guardem relação com o fato investigado (art. 145 CPPN); solicitação do membro do Ministério Público de realizar diligências sem comunicação ao afetado (art. 231 CPPN); sequestro (art. 141 CPPN); interceptação e sequestro [apreensão] de correspondência postal, telegráfica, eletrônica ou qualquer outra forma de comunicação ou de outro efeito transmitido (art. 143 CPPN); apreensão de dados (art. 144 CPPN); devolução de componentes ou destruição de dados apreendidos (art. $144 \mathrm{CPPN}$ ); manutenção dos objetos apreendidos que tenham relação com o processo (art. 145 CPPN); fechamento [interdição] de locais (art. 147 com remissão ao art. 136 CPPN); controle das medidas adotadas pelos membros do Ministério público Fiscal, seus auxiliares ou os funcionários policiais (art. 148 CPPN); condução [coercitiva] de testemunha (art. $\left.152 \S 2 .{ }^{\circ} \mathrm{CPPN}\right)$; exame de DNA, ante a recusa da pessoa em ser examinada (art. $\left.169 \S 7,{ }^{\circ} \mathrm{CPPN}\right)$; reconhecimento de pessoas (art. $171 \mathrm{CPPN}$ ); exames físicos (art. 175 §2. ${ }^{\circ} \mathrm{CPPN}$ ), antecipação de provas (art. 199 e 229 CPPN).

\subsection{Medidas de coerÇão e cautelares}

Por último, acerca das medidas de coerção e cautelares que se podem aplicar a todo o processo, podem-se individualizar as seguintes: controle de legalidade da prisão ou apreensão (art. 61 a CPPN); imposição de medida de coerção (art. 177, 185 e 190 CPPN) - em qualquer fase do processo -; incomunicabilidade do imputado (art. $179 \mathrm{CPPN}$ ); execução de caução (art. 180 CPPN); ordem de prisão do imputado (art. 183 CPPN); prorrogação da prisão (art. $183 \mathrm{CPPN}$ ); excesso de duração nas medidas privativas de liberdade (art. $194 \mathrm{CPPN}$ ); embargo e outras medidas cautelares (art. 186 CPPN); e revisão, prorrogação ou substituição de medida de coerção (art. 190, 192, 193, CPPN).

Em linhas gerais, pode-se afirmar que a oralidade está presente na etapa inicial do processo. Sem embargo, sem uma justificativa ou necessidade visível, o art. 105 do CPPN debilita o regime de audiência como única metodologia de comprovação e tomada de decisões ao não 
materializar o caráter absoluto como se invocou nos princípios gerais (art. 2 CPPN), ao fixar que as audiências se realizarão quando se "requeira um debate prévio ou a produção de prova" (art. $105 \S 2$. CPPN). Esta norma assinala uma restrição inconveniente, pois só contempla a necessidade de audiências em dois requisitos: que seja necessário o contraditório ou enfrentamento entre as partes ou na produção de provas. Então, que se há de fazer com o resto do universo de casos que não abarcam esses pressupostos? Emprega-se a metodologia escrita, que não está contemplada? E por que é mais eficaz? Tudo torna ao problema das práticas judiciais que têm uma forte raiz inquisitiva. É mais fácil não estabelecer diferenças, dado que não deveria haver inconvenientes a que todos tipos de decisões jurisdicionais sejam adotados no marco de uma audiência, desde um mandado de busca solicitado de forma individual, uma recusa [impedimento ou suspeição] ou acordo de procedimento abreviado, apresentado por todas as partes envolvidas.

Gerar alternatividade e multiplicidade de metodologias de trabalho exigirá uma gestão administrativa funcional de cada uma delas. Utilizar um regime de audiências e, por vezes, por escrito, clássico trabalho de despacho, tornará o sistema mais oneroso. Apesar disso, essa regra, tal como fui exposta, não deveria ser considerada uma limitação à oralidade, porque não proíbe que o restante das decisões seja levado adiante de outro modo; porém, seguramente, os operadores judiciais, ao menos na etapa inicial do processo de implantação, em razão das arraigadas práticas culturais inquisitoriais, apoiar-se-ão em sua literalidade para fazer um uso restritivo das audiências e seguir trabalhando como até agora. Esta mesma observação se estende a outras hipóteses que podem ser corrigidas em um processo de implantação e posterior ajuste ou correção.

O novo ordenamento admite que, para o pedido de uma medida de prova como a busca e apreensão domiciliar ou uma interceptação de comunicações, o interessado poderá requerer por "escrito ou em forma oral” e que a realização da audiência dependerá da discricionariedade do juiz interveniente (art. 136 última parte e $143 \mathrm{CPPN})^{9}$.

9 A título de exemplo, não é em nada mais simples e célere materializar uma medida de prova mediante um pedido escrito. Para isso, deve-se confeccio- 
Mas há outras questões que permitem demonstrar que o novo código de processo penal não tem uma técnica legislativa uniforme e depurada para deixar para trás a cultura judicial escrita e altamente formal.

Na verdade, ele não descreve a metodologia (oral ou escrita) em que se sustentará e/ou decidirá. Alguns exemplos disso são: em caso de conversão da ação (art. $33 \mathrm{CPPN}$ ); declaração de revelia (art. $68 \mathrm{CPPN}$ ); desistência do querelante como autor [principal] (art. 84 CPPN); desistência como parte civil [assistente] (art. $96 \mathrm{CPPN}$ ) ou pedido de esclarecimento (art. $107 \mathrm{CPPN}$ ) ou a ordem de prisão (art. $183 \mathrm{CPPN}$ ) que, neste último caso, o juiz decidirá "sumariamente" (denominação que não se repete em outra norma do código e que denota menor rigorosidade do juiz para sua decisão em comparação com outras medidas de prova ou coerção).

Em uma terceira caracterização, por sua redação, infere-se que os pedidos devem ser apresentados de forma escrita e fundamentadamente, com o que não serão decididos na formal oral. Este é o caso de requerimento de libertação antecipada [liberdade provisória] e queixa por demora da justiça (art. $114 \S 1 .^{\circ} \mathrm{CPPN}$ ); atraso de juízes com funções de revisão (art. 115 CPPN) e demora em relação a medidas privativas de liberdade (art. $194 \mathrm{CPPN}$ ).

nar o pedido com um documento escrito que explique o objeto processual e todos os elementos probatórios e jurídicos necessários para justificar a medida, montar um arquivo para anexar a base fática e/ou probatória, que respalda o pedido (o acusador não pode ficar sem o arquivo para seguir paralelamente investigando, o que gera uma duplicidade registral) e sua remessa ao juiz interveniente por um oficial judicial. Depois de recebido o pedido, além do registro, o juiz deve analisar a peça escrita como o resto do arquivo (que pode ter distintos formatos: escrito, áudio e/ou vídeo, segundo os recursos registrais utilizados pelo Ministério Público Fiscal para coletar a evidência), e, ao tomar mesmo brevemente uma decisão, deverá formalizá-la por escrito. Esta sequência não é rápida nem efetiva para uma investigação dinâmica, quando é possível que o acusador se desloque para uma sala de audiências e formule seu pedido de forma oral (ou excepcionalmente a requeira pelo telefone). A preparação escrita do pedido, ainda que seja rápida para essa modalidade, [por] um detalhe deficiente dos elementos probatórios reunidos ou uma má interpretação por parte do juiz interveniente, dilatará ou frustrará qualquer medida. Toda essa falta de uniformidade na regulamentação não é inócua, pois poderá ser geradora de mau funcionamento do sistema. 
Em quarta ordem, não está bem resolvido no código o prazo máximo em que as audiências devem ser realizadas a partir do pedido concreto (p. ex. art. $224 \mathrm{CPPN}$ ). Só estão baseadas em algumas hipóteses, como por exemplo no marco das medidas de coerção (p. ex. art. 190 $\S 4 .^{\circ} \mathrm{CPPN}$ ). Em termos gerais, só se fixaram prazos para decisão, que se computam a partir da conclusão da audiência (sem interrupção, salvo se as partes acordarem um prazo distinto em face da complexidade do assunto a resolver) e, nos casos em que não se requer a realização da audiência, o requerimento deve ser decidido no prazo de três dias (art. 112 CPPN). Esta norma, lamentavelmente, também habilita uma dupla metodologia na tomada de decisões (última parte da norma), mas o que é ainda mais grave é que exclui a decisão como parte relevante da audiência. Os juízes devem decidir na própria audiência, e não imediatamente depois. Será um difícil desafio cultural que os juízes fundamentem e decidam em audiência, quando a lei lhes deixa margem de interpretação autorizando fazê-lo por escrito, o que implica que podem delegar a seus colaboradores a elaboração da minuta de decisão.

\section{ETAPA INTERMEDIÁRIA}

A investigação preparatória se conclui com o requerimento de sobrestamento ou a acusação do imputado (art. 235 CPPN). No primeiro caso, pode concretizar-se com um pedido expresso do Ministério Público (art. 237 e seguintes CPPN) ou por ser procedente um pedido peremptório de exceção [defesa] (art. 37 CPPN). O sobrestamento encerra definitiva e irrevogavelmente o processo em relação ao imputado em favor do qual é proferido e inibe sua nova persecução penal pelo mesmo fato (art. $240 \mathrm{CPPN}$ ). No segundo caso, a acusação deve ser formulada por escrito e conter os dados de identificação do imputado e seu defensor, os fatos, os fundamentos e os meios de prova que sustentam a imputação, as disposições legais aplicáveis, o oferecimento de prova ao juízo, a delimitação do dano e o requerimento de pena estimada (art. $241 \S 10^{\circ} \mathrm{CPPN}$ ). A acusação somente poderá referir-se aos fatos e pessoas incluídas na formalização da investigação, podendo atribuir-se uma qualificação jurídica diferente (art. 241 $\S 2 .^{\circ} \mathrm{CPPN}$ ) ou mesmo formular-se uma acusação alternativa, indi- 
cando alternativamente aquelas circunstâncias do fato que permitem enquadrar o comportamento do imputado em uma figura diversa na lei penal (art. 242 CPPN).

Formulada a acusação, o promotor deve assegurar o conhecimento do seu conteúdo ao querelante, assim como os elementos de prova, no prazo de cinco (5) dias (art. $243 \S 1 .^{\circ} \mathrm{CPPN}$ ). Dentro desse prazo, o querelante [assistente] terá duas opções: aderir à acusação do promotor ou apresentar uma acusação autônoma (que não poderá exceder os limites da formalização). Se se constituiu em autor civil, ademais, deverá especificar sua demanda propondo as provas (art. $243 \S \S 2 .^{\circ}$ e $3 .^{\circ}$ $\mathrm{CPPN}$ ). Findo o prazo, o promotor remeterá à vara judicial sua acusação e, sendo o caso, a do querelante, junto com a demanda civil (art. 243 $\left.\S 4 .^{\circ} \mathrm{CPPN}\right)$. A partir do momento em que recebe a acusação, o cartório judicial deverá, em até quarenta e oito (48) horas, remetê-la ao imputado e seu defensor, por um prazo de dez (10) dias, prorrogáveis por outros dez (10), para os fins do art. 246 do CPPN. Uma das questões não resolvidas expressamente [pelo CPPN] é se a defesa tem de formular, nesse prazo e por escrito, os argumentos preliminares e o oferecimento dos meios de prova para produzir o debate. Poderia fazê-lo, porém, não há obstáculo a formular diretamente os argumentos e o oferecimento de prova no momento da audiência.

Tanto o promotor quanto a defesa, no momento da citação ou da audiência, deverão indicar certos dados na lista de testemunhas para sua correta identificação; o mesmo se aplica à prova documental (se não for possível apresentá-la diretamente, deverão explicar onde se encontram, para que os juízes, a pedido da parte, requisitem ou autorizem sua obtenção). Por sua vez, para facilitar o trabalho do juiz, tanto nesta etapa quanto na etapa do juízo, e para que a parte demonstra solidez e clareza expositiva na teoria do caso, poderia requerer a [demonstração da] pertinência da prova, individualizando ou vinculando cada uma das provas aos extremos da acusação que se pretende sustentar.

Transcorrido o prazo da defesa, a vara judicial convocará as partes e a vítima, se for o caso de sua intervenção, à audiência de controle da acusação, dentro dos cinco (5) dias seguintes (art. 246 § $1 .^{\circ}$ CPPN). Um primeiro ponto de análise é determinar a necessidade de 
que as partes estejam presentes nessa audiência. Embora esse aspecto não esteja exposto de forma explícita, infere-se como um requisito de validade da audiência, pelas questões que se tratarão nela. Se o querelante não se apresenta para formular sua acusação, salvo justificação, implicará tacitamente o abandono da acusação, a desistência da ação ${ }^{10}$. A interrogação é [saber se] essa regra se estende também ao acusador público. No caso da defesa, se tampouco comparece à audiência sem justificação, implicaria colocar o imputado na condição de indefeso, o que obrigaria a suspender a audiência e designar-se um novo defensor para que assuma o trabalho de uma forma efetiva.

Essa audiência, como as restantes, tem uma finalidade multipropósito. Como questão preliminar, a defesa poderá: a. objetar a acusação ou a pretensão civil, apontando os [seus] defeitos formais; b. opor exceções (art. $37 \mathrm{CPPN}$ ); c. instar o sobrestamento; d. propor reparação, conciliação, suspensão condicional do processo ou a aplicação do procedimento abreviado (total ou parcial); e. solicitar que se unifiquem os fatos objeto das acusações quando a diversidade de abordagens ou circunstâncias prejudiquem a defesa; f. pleitear a união ou separação de julgamentos; g. constatar a demanda civil. Resolvidas essas questões, realizar-se-ão os oferecimentos de prova para cada uma das etapas do julgamento e ter-se-ão por incontroversos certos extremos fáticos, que não poderão ser discutidos em juízo (circunstâncias fáticas sobre as quais não exista contradição entre as partes).

Sobre a importância política desta etapa no processo penal, o professor Alberto Binder afirma que "muitas das grandes decisões de política processual que dão conformação [distinção] ao processo penal passam por esta fase intermediária e pelo modo concreto como se controla o resultado da instrução" ${ }^{11}$. Por isso sustentamos que aqui radica um dos

10 Para o querelante se contempla expressamente que “(...) se considera que renunciou à sua intervenção nos seguintes casos: (...) se não formular a acusação na oportunidade processual legalmente prevista (...)”. Por sua vez, não poderá corrigir sua posição com [após] os argumentos da defesa, nem oferecerá prova nem responderá às observações que se formulem a respeito (art. $\left.246 \S 2 .^{\circ} \mathrm{CPP}\right)$.

11 BINDER Alberto: Introducción al Derecho Procesal Penal, $1^{\mathrm{a}}$ ed., Buenos Aires, Editorial Ad-Hoc, 1993, p. 231. 
assuntos principais do trabalho de um sistema processual, porque consiste no último filtro de discussões para a determinação de levar o caso a julgamento. Difere do sistema atual, em que se discute realização do julgamento até o momento mesmo de seu início.

No tocante ao controle da acusação, a partir de uma visão comparada, têm-se notado três regulamentações distintas: 1.- a condução direta a julgamento: à defesa falta a faculdade de questionar o mérito da investigação e só pode invocar exceções [processuais] por carência de ação (extinção, não foi iniciada legalmente, não pode prosseguir, etc.). 2. - o controle da acusação só pode ser gerado a partir da oposição deduzida pela defesa contra a condução a julgamento: se não houver oposição, a condução a julgamento é direta. Neste caso, têm-se percebido dois níveis de controle. Um é o controle de legalidade da acusação (controlar os aspectos meramente formais) ou sua razoabilidade (controle material, analisar o mérito da decisão do acusador, de modo comparado, instar a discutir um processamento adiado à etapa intermediária). 3.- controle obrigatório da acusação: para além do pedido das partes, tanto no aspecto formal quanto no material.

De acordo com o art. 246, inciso a, do CPPN, o imputado e sua defesa, como questão preliminar, na audiência de controle, poderão “objetar a acusação (...) apontando defeitos formais”. Isso repercutirá sensivelmente na prática. Um controle formal habilita potencialmente um maior número de casos a julgamento e poderá sobrecarregar a capacidade dos órgãos jurisdicionais para celebrar julgamentos orais. Essa circunstância deve ser avaliada pelo Ministério Público fixando critérios de "perseguibilidade" [viabilidade e importância da persecução penal], cuja tarefa, em última instância, consistirá em acusar e requerer o envio a julgamento somente aqueles casos que sejam resolvidos apenas mediante a imposição de uma pena; para tanto, haverá de contar com altos níveis de probabilidade de confirmar [provar] a hipótese acusatória.

Sobre o tratamento da admissibilidade da prova, o primeiro ponto a tratar é definir que extremos fáticos da imputação se tenderão por confirmados ante a falta de impugnação pelas partes. Esse acordo é chamado comumente como "convenções probatórias", que podem ser 
propostas pelas partes ou sugerido pelo juiz, mas sempre terá de contar com a soma da vontade dos interessados ${ }^{12}$.

Superado isso, as partes postularão a prova para as etapas do julgamento de determinação de culpabilidade e da aplicação da pena ${ }^{13}$ (no caso de o imputado ser culpável) e formulará requerimentos, observações que entender relevantes com relação às provas oferecidas pelos demais intervenientes (art. $246 \mathrm{CPPN}$ ). A primeira intervenção será formulada pela acusação, enquanto a defesa fará o encerramento dos pleitos.

No caso de não prosperarem as questões preliminares, e admitida total ou parcialmente a prova, elaborar-se-á o que se denomina "auto de abertura e julgamento oral”, que em concreto consiste na delimitação fática, probatória e jurídica do desenvolvimento do debate ${ }^{14}$. Como já exposto anteriormente, o juiz do julgamento não terá acesso a essa peça antes do julgamento.

O auto de abertura do julgamento cumpre, ao mesmo tempo, uma função de garantia: exige que a sentença posterior seja compatível com os fatos pelos quais o juízo foi aberto (princípio da congruência), seja em relação à acusação principal, seja em relação à alternativa.

12 Desde o ponto de vista estratégico, esta prática pode permitir às partes concentrar o objeto do julgamento em aspectos realmente contraditórios e omitir a abordagem daqueles em que não existam posturas antagónicas, o que permitirá encurtar a duração dos debates ao estritamente necessário.

13 N.d.T.: O termo originalmente empregado é cesura que se refere à segunda etapa da audiência de juízo oral e cujo objetivo é determinar a modalidade e a quantidade de pena que será cumprida pelo imputado.

14 Na referida peça, deverão consignar uma série de dados, a saber: a. o órgão jurisdicional competente para intervir no juízo oral; b. a acusação admitida; c. os fatos que se dizem por verdadeiros em razão das convenções probatórias; d. a decisão sobre a admissibilidade ou inadmissibilidade da prova oferecida para o debate e o juízo da pena, com o fundamento; e. os fundamentos pelos quais se rechaça, total ou parcialmente, a oposição da abertura do juízo; f. a decisão acerca da legitimação do querelante para habilitar a abertura do juízo ou para intervir nele e, em caso de pluralidade de querelantes, a ordem de unificar a personalidade, se for procedente; g. quando o acusado suportar uma medida de coerção, a decisão acerca da manutenção da medida ou sua substituição; h. em seu caso, a indicação de como tem sido trabalha a litis na demanda civil e sua contestação (art. 247). 
Com toda a informação contida no auto de abertura do julgamento, o cartório judicial competente poderá planejar de modo preciso o tempo que a audiência de julgamento demorará, de modo tal que se possa realizar uma distribuição de tempo compatível com a complexidade do caso concreto.

\section{Oralidade durante o juízo}

No tópico anterior fizemos referência a que, admitida a acusação na audiência da etapa intermediária, o juiz com funções de garantias formulará um auto de abertura do juízo oral, para que posteriormente o cartório judicial (art. 247. CPPN), no prazo máximo de quarenta e oito horas (48h) - contadas desde o seu recebimento - proceda a planejar e coordenar os trabalhos necessários para a efetiva realização da audiência de juízo oral. Isto implicará, entre outras atividades, sortear o juiz ou juízes que intervirão; fixar o dia e hora da audiência, a qual não se realizará antes de cinco (5) dias nem depois de trinta (30) dias contados a partir do auto de abertura; estabelecer a sala de audiência; citar todas as partes intervenientes; publicar; receber os objetos e documentos que serão apresentados e valorados no debate; e realizar todas as demais medidas necessárias para a organização e desenvolvimento do juízo oral (art. 248 1er. párr. CPPN).

Em casos complexos, ou quando as partes solicitarem, o cartório judicial poderá convocar uma audiência administrativa para resolver questões práticas de organização da audiência (art. 248 3er párr. CPPN), como por exemplo, a ordem de declaração das testemunhas, os requerimentos técnicos necessários para as partes (realizarem alegação com apoio audiovisual); o manejo com a imprensa; etc.

Em relação ao órgão jurisdicional interveniente no juízo oral, o código prevê três possibilidades: unipessoal, colegiado ou jurados. Sobre a última hipótese, o legislador optou por estabelecer as definições sobre sua composição, integração, constituição, substanciação e deliberação à lei especial de juízo por jurados (art. 249 CPPN).

Em todas as hipóteses, o certo é que a audiência de juízo oral é a que apresenta os maiores níveis de contradição no processo penal 
e, eventualmente, realizar-se-á em duas partes: na primeira, a determinação da existência do fato, sua qualificação jurídica e a determinação da responsabilidade do acusado; e, caso seja considerado responsável, a segunda parte consiste em determinar a sanção a ser imposta, sua modalidade e lugar de cumprimento (art. $250 \mathrm{CPPN}$ ).

O debate deverá se realizar com a presença ininterrupta dos juízes e de todas as partes. Concretamente, se o representante do Ministério Público não comparecer, fica estipulado que incorrerá em falta grave e causa de mal desempenho (art. $251 \mathrm{CPPN}$ ), embora não se trate de solução para o caso discutido.

Outro exemplo, uma solução que se ficou estabelecida no projeto de Código Processual Penal apresentado no ano de 2010 (apresentado pelo Deputado Albriu), era considerar que haveria um abandono da acusação: “(...) se o promotor não comparecer, perde a possibilidade de acusar (...)”. Mas a regulamentação do novo código, ao não estabelecer expressamente como uma causa de desistência, deixa aberta a possibilidade para uma nova audiência. Por outro lado, como regra geral, o juízo oral será público (art. $252 \mathrm{CPPN}$ ); o que implicará que se permitirá o acesso do público geral e aos meios de comunicação, às salas de audiência (arts. 253 e $254 \mathrm{CPPN}$ ).

Quanto à intervenção das partes, estas devem ser exclusivamente na forma oral (art. $255 \mathrm{CPPN}$ ), não sendo possível a admissão de pleitos fora do espaço próprio das audiências quando estas requisitarem uma decisão judicial.

Sobre a produção de prova, sua incorporação será através de prova direta e oral das testemunhas e dos peritos (os informes periciais têm caráter de declaração prévia). Também poderá incorporar por leitura e/ou exibição audiovisual: a. as provas recebidas conforme as regras de antecipação jurisdicional de prova, sempre que não seja possível a presença de quem participou ou presenciou o ato; b. a prova documental ou de informes e as certificações; c. os registros de declarações anteriores de testemunhas ou peritos que tiverem morrido ou tornados incapazes física ou mentalmente, ou estiverem ausentes do país, ou cuja residência se ignorava ou que por qualquer outro motivo difícil de superar não puderem declarar em juízo, sempre que elas tiverem sido recebidas notificando previamente a defesa e em con- 
formidade com as demais pautas estabelecidas no código (art. 256 CPPN). Uma das questões que podem trazer controvérsia, é o alcance do termo "prova documental ou os informes". Não poderá ser considerado como tal, os documentos que registram os atos policiais (ex, assalto), pois a informação de como sucedeu esse evento, seu resultado e detalhes, deverão ser introduzidos pelo relato direto e vivo do agente policial que o conduziu ou esteve presente. As distintas suposições deverão se resolver através dos princípios reitores da imediação, concentração e contraditório.

A respeito das habilidades dos juízes na condução das audiências de juízo, foi estipulado que o juiz presidente do debate será quem a conduza, faça as advertências legais, receba os juramentos, modere as discussões e os interrogatórios impedindo intervenções impertinentes, sem restringir o exercício da acusação nem a amplitude da defesa e exercerá as faculdades para disciplina. Também limitará o tempo de uso da palavra das partes que intervirão durante o juízo, fixando limites máximos igualitários para todas as partes ou interrompendo quem fizer uso manifestadamente abusivo do seu direito (art. 257 CPPN). Como se pode advertir, o juiz com funções de juízo terá a direção do debate sem chegar a afetar a imparcialidade, nem a posição estratégica das partes.

Vinculado ao ponto anterior, o código regula que a audiência poderá ser suspensa por um prazo máximo de dez (10) dias se alguma revelação ou retratação for indispensável para a produção de uma medida de prova (art. 258 inc. f CPPN). De acordo com o papel que se espera do juízo, sob nenhuma circunstância deverá assumir uma postura na produção dos meios de prova que forem introduzidos no debate.

Se algum dos convocados como testemunha e/ou perito, não puderem comparecer pessoalmente à audiência por um impedimento justificado, deverão ser ouvidos no lugar em que se encontrem ou mediante meios tecnológicos que permitam receber sua declaração à distância, conforme for apropriado e assegurando a participação das partes (art. 259 CPPN). Sem um sentido prático, a mesma norma, acrescenta ainda a exigência para essas hipóteses, lavrar uma ata para que seja lida na audiência. Isso demonstra como ainda se joga o duelo 
de práticas entre um sistema escrito e um oral, resultando vestígios próprios de um sistema inquisitivo ${ }^{15}$.

No que se refere à primeira fase do juízo, este poderia ser dividido em três momentos: em primeiro lugar, as alegações de abertura (art. 261 CPPN), cujo Ministério Público e/ou querelante, exporão o conteúdo da acusação que consiste em descrever o objeto da imputação e poderá individualizar as provas que serão apresentadas ao longo dos debates, a qualificação legal do fato (e se há acusação alternativa). No caso da defesa, além da conveniência estratégica, não tem a mesma obrigação que a acusação e poderá, eventualmente, apresentar quais são os pontos de contradição, as provas que apresentará para dar crédito à sua teoria sobre o caso ou refutar a sua contraparte e a pretensão que finalmente pretende. O código prevê a possibilidade de que o representante do Ministério Público ou o querelante ampliem a acuação, quando no transcurso dos debates, por uma revelação ou retratação, se tiver conhecimento de uma circunstância do fato que a acusação não continha, que seja relevante para a qualificação legal (art. 262 CPPN). Também neste momento, é a oportunidade de postular as convenções probatórias para reduzir o âmbito de recepção de prova à controvérsia fática.

Como segunda etapa da audiência de responsabilidade, as partes se encarregam de produzir as provas anteriormente oferecidas, para introduzir informação que sustente ou refute suas posturas total ou parcialmente antagônicas. As provas são recebidas na ordem que for acordada pelas partes. No caso de não haver acordo, serão recebidas primeiramente as que tenham sido oferecidas pelo Ministério Público, seguidas das apresentadas pelo querelante e, por último, as propostas pela defesa (art. $263 \mathrm{CPPN}$ ). Será apresentada de forma que as partes as proponham, havendo sempre a possibilidade da outra parte fazer o contra exame. Somente poderá haver um novo exame direto sobre os testemunhos e/ou peritos, quando no contra exame tiver sido produzida uma informação nova que não tinha sido revelada no exame direto (art. 2642 da párr. CPPN). Sobre a formulação das perguntas, no exame dire-

15 A solução mais adequada para essas situações de exceção, é que tais declarações sejam incorporadas normalmente mediante áudio ou vídeo reproduzido durante o curso do debate, inclusive diretamente, sem a necessidade de recorrer à leitura de uma ata (cf. arts. 264 ult. párr. y 332 últ. párr. CPPN). 
to não se admitirá que as partes formulem perguntas sugestivas ou indicativas, que são aquelas que propõem a respostas na própria pergunta; salvo se autorizado para tratamento de uma testemunha hostil ao exame direto (art. 264 3er. párr CPPN). Por sua vez, não se admitirão perguntas enganosas, repetitivas, ambíguas ou destinadas a coagir a testemunha ou o perito (art. 264 5to. párr. CPPN). No exame direto, os litigantes poderão ajudar a testemunha a refrescar sua memória com o uso das declarações formuladas na etapa de investigação. Para o caso do contra exame, será utilizado para destacar as contradições ou inconsistências da testemunha ou do que foi dito (art. 264 4to párr. CPPN) ${ }^{16}$. Outro mecanismo de controle do ingresso da informação, é a possibilidade de objetar (diante de perguntas impertinentes, reiterativas, sugestivas ou capciosas, entre outras), estrategicamente, as perguntas inadmissíveis, que trazem dano à teoria do caso da parte. Em todo momento, poderão ser objetadas as perguntas inadmissíveis indicando o motivo. No entanto, os juízes colocarão imediatamente se o pleito é manifestamente excessivo ou decidirão logo em escutar a réplica da contraparte (art. 264 6ta párr. CPPN). Por último, se fixa que as testemunhas e peritos que, por algum motivo grave e difícil de superar, não puderem comparecer para declarar na audiência de juízo oral, poderão fazê-la através de videoconferência ou qualquer outro meio tecnológico apto para seu exame e contra exame (art. 264 8vo párr. CPPN).

Por sua vez, se estipula a possibilidade do juiz, provocado por petição de alguma das partes, caso seja desconhecida no momento de oferecimento da acusação, possa propor novas provas (art. 267 1er párr. CPPN). E se com a recepção de uma prova surgir uma controvérsia relacionada exclusivamente com sua veracidade, autenticidade ou integralidade, o tribunal poderá autorizar, a partir de petição da parte, a produção de outros meios de informação, ainda que eles não tenham sido oferecidos oportunamente e não fosse previsto a sua necessidade (art. 267 2do. párr. CPPN).

O terceiro e último momento desta audiência está contido no artigo 268 CPPN, sob o título de "discussão final". Isto é o que correntemente se conhece como "alegações finais”: é o único exercício argu-

16 LORENZO, Leticia; Manual de Litigación, Op. Cit., p. 223. 
mentativo que os litigantes podem realizar durante todo o juízo, e é onde expõem aos juízes ou jurados um projeto de sentença sobre como deveriam basear a sua sentença ${ }^{17}$. Nestas alegações finais, os litigantes não poderão ler memoriais, sem prejuízo de leitura parcial de notas (art. 268 2do. párr. CPPN) e se tiver intervindo mais de um representante do Ministério Público, do querelante ou da defesa, todos poderão participar desde que repartindo as tarefas para evitar repetições ou dilações (art. 268 3er. párr. CPPN). Sempre corresponderá ao defensor a última palavra, sem prejuízo das partes poderem replicar (art. 268 4to párr. CPPN). Em último lugar, será perguntado ao imputado se tem algo mais que deseja manifestar e serão convocadas as partes para comunicar a decisão judicial, indicando a hora da sua leitura (art. 268 6to. párr. CPPN).

Finalizada a primeira parte dos debates, o código somente regula a metodologia de deliberação para os juízes de direito (art. 269 CPPN), enquanto que nada se refere para quando os juízes são os jurados populares. Para os processos complexos, a deliberação poderá se estender, excepcionalmente, por um prazo máximo de quarenta e oito (48) horas, salvo motivo de enfermidade grave de algum dos juízes. Neste caso, a suspensão não poderá durar mais que dez dias, e logo em seguida deverá realizar o juízo novamente (art. 269 3er. párr. CPPN). Dentro do prazo de duração da deliberação, os juízes não poderão atuar em outro juízo (art. 269 4to párr. CPPN). Esta exigência obedece a simples necessidade de que os juízes devem concentrar sua memória nos detalhes e informações do juízo para poder adotar uma decisão, sem interferência de informação de um outro juízo.

A segunda fase do juízo é chamada audiência de determinação da pena ou de cesura ${ }^{18}$ (art. $270 \mathrm{CPPN}$ ), que somente terá lugar se houver uma declaração de responsabilidade. Se ocorrer, será fixado dentro das quarenta e oito (48) horas, debate para determinar o tipo e quantidade de pena, assim como a modalidade de cumprimento. Se tiver sido exercida a ação civil, estabelecerão a indenização, se for cabível. Nesta audiência, as partes apresentarão a prova oferecida na etapa intermedi-

17 LORENZO, Leticia; Manual de Litigación, Op. Cit., pp. 241-245.

18 N.d.T.: Termo originalmente empregado pelos autores. 
ária, argumentarão sua incidência para a medida da pena e formularão seus pedidos concretos.

Para a prolação da sentença, deverão ser cumpridos os seguintes requisitos: a. o lugar e a data em que se pronuncia, a composição do órgão judicial, o nome do ou dos juízes e as partes, os dados pessoais do imputado e o enunciado do fato que foi objeto da acusação e, se for o caso, da ação civil; b. o voto dos juízes sobre cada uma das questões levantadas, com exposição dos motivos que o fundamentam; c. a determinação precisa e circunstanciada do fato que se se está julgando; e d. a parte dispositiva com menção das normas aplicáveis; e. a assinatura dos juízes (art. $271 \mathrm{CPPN}$ ).

A sentença será redigida e assinada imediatamente depois da última deliberação. Os juízes se reunirão novamente na sala de audiência, depois de convocar verbalmente as partes e o público. O documento será lido em voz alta para todos que comparecerem (art. 272 1er. párr. CPPN). Porém, está previsto que os juízes podem protelar a redação da sentença no prazo não superior a cinco (5) dias (art. 272 2do. párr. CPPN). Se for verificada a suspensão prevista no art. 258 (continuidade, suspensão e interrupção da audiência), o prazo estabelecido será de dez (10) dias e se poderá estender até vinte (20) dias quando a audiência tiver sido prolongada por amis de três (3) meses (art. 272 4to. párr. CPPN). No caso dos processos catalogados judicialmente como complexos, os prazos serão duplicados (art. 294 inc. e CPPN).

Outro aspecto relevante vinculado com os requisitos da decisão, é a sua relação que deve ter com a acusação (art. 273 CPPN). Não poderão ser imputados outros fatos ou circunstâncias diversos dos que já foram descritos na acusação e, dependendo do caso, na ampliação da acusação. Tão pouco se dará ao fato uma qualificação jurídica distinta, salvo se for em benefício do imputado sempre que tenha sido objeto de debate (art. 273 1er. párr. CPPN). Não poderá ser imposta uma pena mais grave que solicitada pelos acusadores e deverão absolver no caso em que ambas partes requeiram (art. 273 2do. párr. CPPN). Em definitivo, os juízes só poderão resolver o que tenha sido matéria de debate.

Um dos trabalhos principais do cartório judicial no âmbito da audiência, será o registro. Este trabalho, que ficará a cargo de um servidor da secretaria sem necessidade de comprovação da autenticidade 
dos documentos ${ }^{19}$, poderá desenvolver de dois modos distintos: para dar assistência à gravação do vídeo (com conteúdo sucinto), dado que o fundamental é o suporte audiovisual (art. $276 \mathrm{CPPN}$ ). O registro audiovisual permite maior precisão do que ocorre no desenvolvimento do debate, e terá maior eficácia, mesmo para as impugnações.

\section{Oralidade nos Recursos}

O regime de revisão das decisões judicias regulado pelo código é um modelo de controle de caráter estrito ou taxativo. Desde um aspecto objetivo, as decisões judiciais só poderão ser questionadas pelos meios e apenas nos casos expressamente estabelecidos pelo texto do código (art. 297 1er. párr. CPPN).

Enquanto que, em relação ao aspecto subjetivo, o direito de recorrer corresponderá apenas a quem for expressamente reconhecido e demonstre um interesse na anulação, revogação ou reforma da decisão impugnada, podendo o Ministério Público recorrer, inclusive, em favor do imputado (art. 297 2do. párr. CPPN).

As regras de impugnação reguladas pelo novo código de processo penal federal se comprometem com uma visão completamente distinta: um sistema de recursos compatíveis com o sistema de garantias e construído com o fim de reduzir os erros judiciais. Isto implica, por um lado, que o objetivo principal é o de atender ao interesse apresentado pelas partes, o que converte o recurso em garantia individual; por outro lado, se vem construindo de tal modo que se preserve o juízo como o espaço central de realização das garantias e que ao mesmo tempo transfira os princípios da oralidade, publicidade e imediação para a instância recursal.

No que diz respeito ao trâmite administrativo, a impugnação será interposta por escrito, devidamente fundamentada, perante juiz que prolatou a decisão, dentro do prazo de dez (10) dias se se trata de uma sentença condenatória ou absolutória; de três (3) dias se for caso

19 Originalmente, foi utilizado o termo facultades de fedetarios que diz respeito à fé-pública que atesta autenticidade de documentos (notas dos tradutores). 
de aplicação de medida cautelar e de cinco (5) dias nos demais casos, salvo hipóteses previstas no código de revisão imediata (art. 313 1er. párr. CPPN). A norma estipula que a interposição do recurso é perante o juiz que prolatou a sentença, quando na verdade isto se realiza perante a secretaria do cartório judicial, como de fato esta é uma das suas funções, servindo de apoio à atividade jurisdicional.

Em suma, os trabalhos que o cartório judicial deverá cumprir se concentram em: traslado de cópias da impugnação para as outras partes (art. 313 5to. párr. CPPN); sortear os juízes que intervirão (sejam os compostos por colegiado de juízes ou aqueles que seguem operando da maneira tradicional) e marcar a audiência dentro de cinco (5) dias desde a última comunicação (art. 313 7mo. párr. CPPN).

Um ponto que não está claramente expresso no código é o modo em que se dará o exame de admissibilidade. Existem diversos modos de organizar esta tarefa: através de uma unidade especial de admissibilidade, composta por juízes que integrem o tribunal; a cargo de um ou mais funcionários do cartório judicial; ou fazer no início da audiência, na presença das partes. Um aspecto determinante para escolher um dentre esses modelos será de acordo com a carga de trabalho que cada tribunal tenha.

Como último tópico a ser enfrentado, nos referiremos à sustentação do recurso na audiência, a função do juiz e o papel das partes nesse marco conforme a etapa processo da qual emana a impugnação. Um primeiro aspecto, é que a audiência será celebrada com a convocação de todas as partes, que deverão apresentar oralmente os fundamentos da sua impugnação (art. 314 CPPN), para além da interposição escrita inicial. Isso é em si mesmo uma mudança absoluta na lógica de trabalho em respeito ao atual sistema, pois significa que serão as partes quem devem expor em audiência, os motivos pelos quais pretende que a decisão seja modificada ou confirmada. Se o impugnante requer a produção de prova, a oferecerá junto com a petição de interposição, assinalando de forma concreta o fato que se pretende provar, e ficando a sua responsabilidade de apresentá-la (art. $314 \mathrm{CPPN}$ ).

Um segundo aspecto, se vincula com a postura dos juízes nessas audiências. O código estipula que promoverão o contraditório entre as partes com o propósito de escutar as diversas opiniões sobre o objeto 
de impugnação e, ademais, poderão interrogar os recorrentes sobre as questões pleiteadas e seus fundamentos legais, doutrinários ou jurisprudenciais (art. $314 \mathrm{CPPN}$ ). Isso claramente difere com o que está previsto no art. 105 CPPN (resoluções judiciais) que fixa o contrário: “(...) O juiz não poderá suprir a atividade das partes, e deverá sujeitar-se ao que tenha sido discutido (...)".

Embora o código não faça uma distinção, o certo é que a sustentação do recurso em audiência varia segundo se trata de um recurso produto do juízo oral ou das etapas anteriores.

No caso das impugnações que se originam antes ao juízo, a amplitude de tratamento dos pleitos será de forma tal que na audiência poderão ser reeditados os pleitos formulados ao juiz de garantias e incorporar novas provas, novos argumentos probatórios e jurídicos. Por outro lado, no caso de recurso de uma sentença de um juízo oral terá duas alternativas: que seja contra uma sentença advinda de um tribunal profissional ou um veredito de um jurado popular. Enquanto nós sustentamos que não deveriam existir divergências entre ambas metodologias, a tradição acadêmica e as recentes experiências nas províncias de nosso país nos indicam que estão sendo diferentes ${ }^{20}$. A isso se soma o que se tem feito pela doutrina do "máximo esforço revisor" decorrente do caso "Casal" da Corte Suprema de Justiça da Nação, que, em poucas palavras, estipulou que o tribunal de cassação deve esgotar o esforço por revisar tudo o que possa ser revisado, ou seja, esgotar a revisão do que pode ser revisado (considerando 23) e que os únicos que não sejam passíveis de revisão sejam os que surjam direta e unicamente da imediação (considerando 24).

Em relação aos prazos a que estão submetidos os juízos com funções de revisão, o código estipula que se a decisão impugnada for uma sentença, ditarão a decisão dentro de vinte (20) dias a contar de quando ocorreu a audiência; enquanto que em outros casos, os juízes

20 O caso mis concreto pode ser encontrado na província de Neuquén, onde no começo desse ano se gerou uma interessante discussão ao redor da metodologia recursiva nos casos de sentenças e vereditos. Um resumo destes debates pode ser encontrado no seguinte link: <https://medium.com/@ FdelExpediente/impugnacion-y-jurados-populares-3195c16e3243>. Acesso em: 25 jul. 2017. 
deverão resolver de imediato, dando os fundamentos para finalizar a audiência, exceto se as partes acordarem em um prazo maior em razão de novos fatos ou complexidade do assunto (art. 315 CPPN).

Em definitivo, acreditamos que a discussão sobre a estrutura e o modo de trabalho de um sistema recursivo compatível com as exigências de um modelo acusatório não se esgota nesses tópicos que foram desenvolvidos, mas apresentamos os pontos de maior resistência para conseguir uma mudança de paradigma estrutural no modo de controlar as decisões judiciais.

\section{Oralidade na etapa de execução penal}

Nesta última etapa, o regime de audiências para a formulação de petições para apreciação judicial se aplica para todos os casos (art. 323 y $332 \mathrm{CPPN}$ ), exceto para o caso de cômputo da pena. De todo modo, a competência do juiz não é "passiva”, espera de uma pretensão das partes; também de modo ativo deverá "visitar periodicamente [pelo menos semestralmente] os estabelecimentos onde se encontrem pessoas privadas da sua liberdade" (art. 57 inc. e CPPN y cf. 208 ley 24.660).

Os pleitos que o Ministério público, o condenado ou seu defensor, pretendem formular nesta etapa serão diretamente perante o juiz com funções de execução penal. Não apenas serão apresentados de forma direta, sem mediação por uma petição escrita, como também deverão ser resolvidos na mesma audiência, com a presença das partes (art. 332 1er. párr. CPPN).

A intervenção do condenado nas audiências é uma questão essencial e contempla o uso de recursos tecnológicos em casos de limitação pela distância entre o lugar em que se encontra preso e a sede dos juízes da execução. Para recorrer a essa conexão, "deverá ser assegurado a privacidade da comunicação entre o condenado e seu defensor durante todo o seu desenvolvimento" (332 5 párr. CPPN).

É admissível a produção de prova durante a audiência, devendo a parte que propõe apresentá-la obter uma autorização judicial na mesma audiência, que só poderá ser rejeitada quando não tiver vin- 
culação com o pedido (impertinente) ou considere já provado em excesso uma circunstância fática invocada (superabundante). Se deverá admitir qualquer meio de prova e de não contar com possibilidades de apresenta-la em audiência por questões alheias a sua vontade se contempla a possibilidade de requerer o auxílio judicial, para o qual se deve requerer ordem do juiz ou do cartório judicial (art. 3322 do. párr. CPPN).

Todas as decisões do juiz da execução poderão ser revisadas diante de pedido expresso das partes dentro do prazo de cinco dias de prolatada (art. $333 \mathrm{CPPN}$ ), embora entendemos que não houvesse impedimento de interpuser na mesma audiência ao individualizar os motivos do recurso, deixando para a audiência perante os juízes a possibilidade de rever o desenvolvimento dos agravos.

Com a formulação do pedido de revisão, ao cartório judicial corresponde o dever de sortear os três juízes de revisão, que não podem ter atuado anteriormente no caso, e fixar data para a celebração de uma audiência dentro de cinco dias. Para a revisão, as partes deverão expor seus argumentos, primeiro o recorrente e logo depois os restantes; para que os juízes, logo após deliberarem, emitam imediatamente sua decisão de forma fundamentada. Embora a norma não o mencione expressamente, é razoável entender que o indivíduo submetido `sanção também deve intervir nas audiências de revisão.

Sobre o desenvolvimento da audiência, não se estabelecem maiores detalhes, então a dinâmica dependerá da interpretação das regras que adotem os juízes. Os interrogantes gerados no início do novo sistema podem ser: se se deve reproduzir a totalidade do registro audiovisual da audiência do juiz da execução (substituindo a leitura dos fundamentos que se poderia fazer em uma sentença feita por escrito), ou se pode oferecer nova prova. Sobre a primeira incógnita, apoiamos a postura segundo a qual não é necessário a reprodução da audiência anterior, devendo as partes exercerem corretamente o sentido do contraditório, devendo a parte controlar a qualidade da informação que introduz a parte contrária. Na realidade, toda a informação introduzida na audiência, tem que estar sob o exame da contraparte, que em sua exposição poderá manifestar-se sobre as omissões ou erros do recorrente. Em tais casos, o recorrente explicará qual é a petição 
inicial e no que se baseou; seguirá relatando a decisão a qual se agrava e seus motivos, e finalmente, explicará os fundamentos pelos quais pretende a revogação ou modificação. Somente quando a controvérsia não se puder ser resolvida, recorrerá a reprodução total ou parcial da audiência prévia.

A respeito ao tipo de pleitos na etapa da execução penal que contempla expressamente o novo Código de Processo Penal, mencionamos os seguintes: 1.- De caráter geral, todos os pleitos suscitados durante a execução das penas e medidas de segurança ou educativas (art. 56 inc. c CPPN); 2.- Unificação de penas ou condenação (arts. 56 inc. "g" e 329 CPPN); 3.- Diferimento da execução (art. 330 CPPN); 4.- Regras de conduta; 5.- Cumprimento em um estabelecimento de saúde (art. $334 \mathrm{CPPN}$ ); 6.- Multa (art. $335 \mathrm{CPPN}$ ): para prorrogação do prazo de pagamento, parcelamento ou substituição; 7.- Inabilitação (art. $336 \mathrm{CPPN}$ ); 8.- Expulsão de condenados estrangeiros em situação irregular no país (art. 56 inc. d CPPN); 9.- resolver impugnações que se apresentem contra decisões administrativas penitenciárias (art. 56 inc. g. CPPN); 10.- revisão de sentenças condenatórias quando entrarem em vigor uma lei penal mais benéfica (art. 56 inc.. f CPPN) e 11. Revisão (art. 333 CPPN).

Como se mencionou anteriormente, o cômputo da pena privativa de liberdade (art. 328 CPPN) ou de inabilitação (art. 336 1er. CPPN) é a única hipótese na etapa da execução penal que se resolve sem audiência. Logo que o cartório judicial (oficina judicial) recebe uma cópia da sentença condenatória, é dado conhecimento ao juiz para que realize o cômputo da pena, fixando a data em que finaliza a condenação e tudo o que implicar em saída transitória ou definitiva do condenado, em conformidade com a lei de execução penal. As partes serão comunidades e as mesmas terão acesso dentro de três dias. A oposição ao cômputo se materializará em audiência, na qual o juiz decidirá antes de escutar as partes. Essa decisão poderá ser revisada por três (3) juízes dentro do prazo de cinco (5) dias de interposta a revisão por escrito perante o cartório (art. $333 \mathrm{CPPN})$.

Neste ponto, os autores deste trabalho possuem posições antagônicas. Por esse motivo, serão expostas conforma a opinião de cada um. Um, não vislumbra questionamentos à exceção porque seria sobrecarga 
ao trabalho nas audiências dos juízes com função de execução e que esse trabalho, por sua condição administrativa, deveria ser realizado pelo cartório judicial (oficina judicial). Esta última poderia solicitar maior informação às partes em caso de necessidade e a parti dela praticar o cômputo, sem ter que movimentar o processo de celebração de uma audiência específica para esta finalidade. Somado a isso, convém recordar que na atualidade, tanto a nível comparado como na justiça federal em concreto, o recurso "juiz de execução" é de caráter limitado, o que desde uma visão pragmática não haveria necessidade de sobrecarregar seu trabalho com uma tarefa que poderia realizar o próprio cartório judicial por meio de uma unidade de execução. A outra opinião, por outro lado, destaca negativamente a falta de regulação do cômputo da pena em audiência quando são as partes que contam com maior informação sobre o caso concreto, e os antecedentes do imputado. Ao contrário, a informação com que pode contar o juiz de execução ou o cartório judicial são limitadas, pois os autos da execução penal só se constituem inicial com uma cópia da sentença condenatória (art. $327 \mathrm{CPPN}$ ), peça processual que geralmente não faz menção aos prazos de detenção do indivíduo durante o caso ou outros processos paralelos. Por sua vez, o cômputo de detenção não é motivo de debate nem deliberação em nenhuma das duas etapas do debate; mesmo o juiz da execução não poderia ter acesso ao auto de abertura do juízo oral. Mas ademais, o sistema adversarial regerá em todas as etapas do processo e não somente até o debate ou a revisão da sentença, pelo qual o órgão jurisdicional ou o cartório de apoio não deveriam atuar de ofício completando a informação ausente nos autos da execução.

\section{CONCLUSÃo}

A reforma da justiça penal federal da Argentina tem dado somente o primeiro passo com a sanção do novo Código de Processo Penal da Nação e que este processo apenas inicia um grande e complexo caminho de múltiplas dimensões.

A primeira dimensão é precisamente normativa. No presente trabalho descrevemos a estrutura e dinâmica processual com a qual o 
novo código se compromete. Na dimensão estrutural, se tem regulou um sistema de audiências orais para a doção das decisões judiciais, no marco segundo o qual se redefine os papéis dos atores processuais que intervém no procedimento penal. Em fins gerais, estamos em condições de concluir, comparativamente, que se trata de um bom texto normativo, para além das observações negativas que foram manifestadas. Estas podem ser sanadas com uma adequada implementação, ainda que seja pouco provável.

Existem numerosas experiências latino-americanas que tem demonstrado que grande parte do êxito das reformas se joga em como induzir e trabalhar a enorme mudança cultural que supõe uma transformação da magnitude da que se trata a reforma federal argentina.

\section{Bibliografía}

BINDER Alberto. Implementación de la nueva justicia penal adversarial. Buenos Aires: Ad-hoc, 2012.

BINDER Alberto. Independencia judicial y delegación de Funciones: El extraño caso del Dr. Jekyll y Mr. Hyde. In: BINDER Alberto. Justicia Penal y Estado de Derecho. $2^{\circ}$ ed. Buenos Aires: Ad-Hoc, 2011.

BINDER Alberto. Código-mentira al servicio judicial: algo más sobre la delegación de funciones. In: BINDER Alberto. Justicia Penal y Estado de Derecho. $2^{\circ}$ ed. Buenos Aires: Ad-Hoc, 2011.

BINDER Alberto. Introducción al derecho procesal penal. Buenos Aires: Ad Hoc, 2005.

CANO JARAMILLO, Carlos Arturo. Oralidad, Debate y Argumentacion. Bogota: Editorial Ibañez, 2007.

GARCIA YOMHA, Diego; MARTINEZ, Santiago. La oralidad de decisiones durante la ejecución de la pena. In: Sistemas Judiciales, CEJA, Año 6, No 11.

GONZALEZ PRECIADO, Mireya. Oralidad y gestión, el reto de hoy. In: Reformas Procesales Penales en América Latina, Discusiones Locales. Santiago: CEJA, 2005.

LEDESMA Ángela E. La reforma procesal penal. Buenos Aires: Editorial Jurídica Nova Tesis, 2005.

LORENZO, Leticia. Manual de Litigación. Buenos Aires: Ediciones Didot, 2012. 


\section{Informações adicionais e declarações dos autores (integridade científica)}

Declaração de conflito de interesses (conflict of interest declaration): os autores confirmam que não há conflitos de interesse na realização das pesquisas expostas e na redação deste artigo.

Declaração de coautoria e especificação das contribuições (declaration of authorship): todas e somente as pessoas que atendem os requisitos de autoria deste artigo estão listadas como autores; todos os coautores se responsabilizam integralmente por este trabalho em sua totalidade.

- Leonel González Postigo: projeto e esboço inicial, coleta e análise de dados, levantamento bibliográfico, redação do artigo.

- Tobías José Podestá: projeto e esboço inicial, coleta e análise de dados, levantamento bibliográfico, redação do artigo.

- Tradução do espanhol ao português (com posterior revisão dos autores): Caíque Ribeiro Galícia e Vinícius Diniz Monteiro de Barros.

Declaração de ineditismo e originalidade (declaration of originality): versão resumida em português inédita de artigo originalmente publicado em espanhol em: GONZÁLEZ POSTIGO, Leonel; JOSÉ PODESTÁ, Tobías. Oralidad en el nuevo Código Procesal Penal de la Nación Argentina. Revista de Derecho Procesal Penal, Santa Fe, Argentina, 2015; os autores asseguram que não há plágio de terceiros ou autoplágio. 
Dados do processo editorial

(http://www.ibraspp.com.br/revista/index.php/RBDPP/about/editorialPolicies)

- Recebido em: 24/06/2017

- Tradução e revisão: 16/07/2017

Equipe editorial envolvida

- Versão final: 28/07/2017

- Autores convidados

http://www.ibraspp.com.br/revista/index.php/

RBDPP/about/editorialPolicies - custom-1

- Editor-chefe: 1 (VGV)

- Editora-associada: 1 (FMB)

- Editora-assistente: 1 (CRG)

\section{COMO CITAR ESTE ARTIGO:}

GONZÁLEZ POSTIGO, Leonel; JOSÉ PODESTÁ, Tobías. A oralidade no novo código de processo penal da nação Argentina. Revista Brasileira de Direito Processual Penal, Porto Alegre, vol. 3, n. 3, p. 849-878, set./dez. 2017. https://doi.org/10.22197/rbdpp.v3i3.89

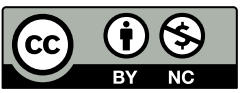

Esta obra está licenciada com uma Licença Creative Commons Atribuição-NãoComercial 4.0 Internacional. 